\title{
Dietary tissue cadmium accumulation in an amazonian teleost (Tambaqui, Colossoma macropomum Cuvier, 1818)
}

\author{
Matsuo, AYO.* and Val, AL. \\ Laboratório de Ecofisiologia e Evolução Molecular, Instituto Nacional de Pesquisas da Amazônia, INPA, \\ Av. André Araújo, 2936, CEP 69083-000, Aleixo, Manaus, Amazonas, Brazil \\ *e-mail: amatsuo@nd.edu
}

Received December 13, 2005 - Accepted February 22, 2006 - Distributed November 30, 2007

(With 4 figures)

\begin{abstract}
Understanding the effects of metal contamination in the Amazon basin is important because of the potential impact on this region of high biodiversity. In addition, the significance of fish as the primary source of protein for the local human population (living either alongside the Amazon River or in the city of Manaus) highlights the need for information on the metal transfer through the food chain. Bioaccumulation of metals in fish can occur at significant rates through the dietary route, without necessarily resulting in death of the organism. The goal of this work was to expose an economic relevant species from the Amazon basin (tambaqui, Colossoma macropomum) to dietary cadmium (Cd) at concentrations of $0,50,100,200$, and $400 \mu \mathrm{g} . \mathrm{g}^{-1}$ dry food. Fish were sampled on days 15,30 , and 45 of the feeding trials. Tissues were collected for analysis of $\mathrm{Cd}$ concentration using graphite furnace atomic absorption spectrophotometry. Cd accumulation in the tissues occurred in the following order: kidney $>$ liver $>$ gills $>$ muscle. Relative to other freshwater fish (e.g., rainbow trout, tilapia), tambaqui accumulated remarkably high levels of $\mathrm{Cd}$ in their tissues. Although Cd is known to affect $\mathrm{Ca}^{2+}$ homeostasis, no mortality or growth impairment occurred during feeding trials.
\end{abstract}

Keywords: dietary cadmium, tissue accumulation, Colossoma macropomum, Amazon, soft water.

\section{Acúmulo dietário de cádmio em tecidos de um teleósteo Amazônico (Tambaqui, Colossoma macropomum)}

\begin{abstract}
Resumo
O entendimento dos efeitos da contaminação por metais na Bacia Amazônica é importante devido ao potencial impacto sobre esta região de elevada biodiversidade. Além disso, a relevância dos peixes como fonte primária de proteína para a população humana local (tanto nas comunidades ribeirinhas ao longo do rio Amazonas, quanto na cidade de Manaus), ressalta a necessidade de informação sobre a transferência de metais através da cadeia alimentar. Bioacumulação de metais em peixes pode ocorrer em taxas significativas através da dieta, sem necessariamente resultar na morte do indivíduo. O objetivo deste estudo foi expor cronicamente uma espécie de importância comercial nativa da Amazônia (tambaqui, Colossoma macropomum) a dietas enriquecidas com cádmio (Cd) em concentrações de 0, 50, 100, 200, and $400 \mu \mathrm{g} \cdot \mathrm{g}^{-1}$ alimento seco. Os peixes foram amostrados nos dias 15, 30 e 45 do tratamento experimental. Os tecidos foram coletados para análise quanto a concentração de $\mathrm{Cd}$ por meio de espectrofotometria de absorção atômica acoplado a forno de grafite. $\mathrm{O}$ acúmulo de $\mathrm{Cd}$ nos tecidos ocorreu na seguinte ordem: rim $>$ fígado $>$ brânquias $>$ músculo. Comparando-se com outras espécies de peixes de água doce (por exemplo, truta arco-íris, tilápia), o tambaqui acumulou níveis de Cd extremamente mais elevados em seus tecidos. Apesar do Cd ser conhecido por afetar a homeostase do $\mathrm{Ca}^{2+}$, não houve mortalidade ou retardo no crescimento durante os testes dietários.
\end{abstract}

Palavras-chave: Cádmio, bioacumulação tecidual, Colossoma macropomum, Amazônia, água doce.

\section{Introduction}

In the Amazon basin, natural waters are highly susceptible to metal contamination because of the intense industrial activity occurring in urban areas. Cadmium (Cd), a non-essential metal, can be extremely toxic to fish, interfering primarily with calcium $\left(\mathrm{Ca}^{2+}\right)$ homeostasis (Verbost et al., 1989). Estimates of Cd release into Amazonian waters from industrial sources are not avail-

able, but the intensity of industrial activity in Amazonas, Brazil, is a likely source of this metal. For example, the formation water, associated with petroleum extraction processes along the Amazon River, has elevated Cd levels (10 $\mu \mathrm{g} . \mathrm{L}^{-1}$; Oliveira, 2003), and the release or spillage of this effluent to the aquatic environment constitutes a major concern. 
Cd contamination represents a significant threat to Amazonian fish, particularly because of the soft nature of the water bodies in the basin. Calcium $\left(\mathrm{Ca}^{2+}\right)$, one of the major hardness cations, is usually present at concentrations $<180 \mu \mathrm{mol} . \mathrm{L}^{-1}$ in Amazonian waters (Furch, 1984). It is widely known that the toxic effects of metals like $\mathrm{Cd}$ to fish increase in soft water compared to hard water, because of the low availability of hardness cations to out-compete the toxic forms for binding sites on the gills (e.g., Playle et al., 1993).

We previously determined the sensitivity of a native Amazonian fish (tambaqui, Colossoma macropomum) to waterborne $\mathrm{Cd}$ toxicity in soft water (Matsuo et al., 2005). Because Cd accumulation in fish can be proportionally higher through dietary exposure than through waterborne exposure (e.g., Szebedinszky et al., 2001; Berntssen et al., 2003; Baldisserotto et al., 2005), the goal of the present study was to assess the chronic accumulation of $\mathrm{Cd}$ in the tissues of tambaqui following exposure to Cd-enriched diets. We also measured the specific growth rates (SGR) during the feeding trials to assess the possibility of growth impairment following dietary $\mathrm{Cd}$ exposure.

\section{Material and Methods}

\subsection{Experimental animals}

Juvenile tambaqui $(8.52 \pm 0.43 \mathrm{~g})$ obtained from Embrapa (Empresa Brasileira de Pesquisas Agropecuárias, Manaus, Amazonas, Brazil) were kept in $100 \mathrm{~L}$ polyethylene tanks in aerated, soft wellwater for at least 3 weeks before we began experimentation. Soft water consisted of wellwater with an average composition of: $\mathrm{Ca}^{2+}=11, \mathrm{Na}^{+}=34, \mathrm{Cl}^{-}=28, \mathrm{Mg}^{2+}=0.8, \mathrm{~K}^{+}$ $=15$ (all in $\mu \mathrm{mol} . \mathrm{L}^{-1}$ ); $\mathrm{pH} 6.3$; dissolved organic matter $(\mathrm{DOM})=0.9 \mathrm{mg} \mathrm{C} \mathrm{L}{ }^{-1}$; background $\mathrm{Cd}=0.3 \mu \mathrm{g} . \mathrm{L}^{-1}$; temperature $=28{ }^{\circ} \mathrm{C}$.

\subsection{Experimental diets}

To determine the influence of dietary $\mathrm{Cd}$ on tissue metal burden, we exposed tambaqui to long-term ingestion of substantially contaminated food (30 fish per tank, $\mathrm{N}=2$ replicates for each treatment). Experimental diets were prepared based on the methodology of Szebedinszky et al. (2001). Commercial dry fish food pellets $(27 \%$ crude protein, $10 \%$ crude fat, $43 \%$ crude carbohydrate, $0.8 \% \mathrm{Na}^{+}, 1 \% \mathrm{Ca}^{2+}$ ) were ground to a fine powder using a blender. To obtain the desired $\mathrm{Cd}$ concentrations in the experimental diets, we dissolved $\mathrm{Cd}\left(\mathrm{NO}_{3}\right)_{2} \cdot 4 \mathrm{H}_{2} \mathrm{O}$ in deionized water, and then added this solution to the ground food. For example, to obtain a diet of $100 \mu \mathrm{g}$ of $\mathrm{Cd} \mathrm{g}^{-1}$ dry food, we dissolved $100 \mathrm{mg}$ of $\mathrm{Cd}$ in $500 \mathrm{~mL}$ of deionized water and added this solution to $1 \mathrm{~kg}$ of the ground fish food. Experimental diets were then homogenized manually and mechanically, by passing it through a meat grinder several times before extruding the final pellets. The pellets were arranged on trays and allowed to air-dry for 24-48 hours. Once dried, the pellets were broken down manually to fit the mouth size of the experimental fish and stored at $4{ }^{\circ} \mathrm{C}$ in labeled containers. The control diet was prepared without any added $\mathrm{Cd}$ solution. Tambaqui were initially trained to feed on control food for at least 3 weeks prior to being fed the experimental diets.

Each set of replicates was fed a diet containing nominal 0 (control), 50,100, 200, or $400 \mu \mathrm{g}$ of $\mathrm{Cd} \mathrm{g}^{-1}$ dry food (Table 1). Tambaqui were fed the experimental diet at approximately $2 \%$ body weight once daily. Tanks were siphoned within 30 minutes after the daily feeding to remove residual food and fecal material from water. The daily routine during feeding trials also included approximately $95 \%$ of the water renewal in the tanks. Exposure to $\mathrm{Cd}$ enriched diets did not result in mortality during the feeding period.

\subsection{Sampling}

On days 15,30 , and 45 of the feeding period, 10 fish from each tank were collected randomly and killed using an overdose of anesthetic (1 g.L - $^{-1}$ MS-222, Sigma) and tissues (gill, muscle, liver, and kidney) were sampled for analysis of Cd content. Tissue samples were vigorously rinsed in deionized water, blotted dry, and transferred to pre-weighed vials. Samples were digested in $1 \mathrm{~N} \mathrm{HNO}_{3}$ at $70{ }^{\circ} \mathrm{C}$ for $24-48$ hours. Tissue digests were quickly spun and supernatant was diluted 1000 times in $0.1 \mathrm{~N}$ $\mathrm{HNO}_{3}$ for analysis of $\mathrm{Cd}$ concentration using graphite furnace atomic absorption spectrophotometry (AAnalyst 800-GF, Perkin Elmer). Tissue samples from the control fish (fed Cd-free diets) did not require dilution for $\mathrm{Cd}$ concentration analysis.

\subsection{Specific growth rate}

To assess the possibility of growth impairment in tambaqui exposed to Cd-enriched diets, we calculated the specific growth rate (SGR) following Szebedinszky et al. (2001). SGR, in \% day ${ }^{-1}$, was estimated based on tank biomass measurements $(\mathrm{N}=2$ replicates for each treatment) over the feeding period, as follows:

$\mathrm{SGR}=\left(\left[\ln \left(\mathrm{w}_{2}\right)-\ln \left(\mathrm{w}_{1}\right)\right] \cdot \mathrm{t}^{-1}\right) \times 100$

where $\mathrm{w}_{1}$ and $\mathrm{w}_{2}$ represent the bulk weight of fish $(\mathrm{g})$ at the start and the end of the feeding period, respectively, and $t$ is the length of the feeding period $(d)$.

Table 1. Cd concentration in diet and SGR values

\begin{tabular}{lcc}
\hline $\begin{array}{c}\text { Nominal [Cd] } \\
\left(\mu \text { g.g }^{-1} \text { dry food) }\right.\end{array}$ & $\begin{array}{c}\text { Measured }[\mathrm{Cd}] \\
\left(\mu \text { g. }^{-1} \text { dry food) }\right.\end{array}$ & $\begin{array}{c}\text { Specific growth } \\
\text { rate (SGR) } \\
(\% / d a y)\end{array}$ \\
\hline 0 (control) & $2.4 \pm 0.7$ & $2.72 \pm 0.29$ \\
50 & $60.6 \pm 3.3$ & $2.34 \pm 0.12$ \\
100 & $115.2 \pm 4.9$ & $2.27 \pm 0.24$ \\
200 & $241.1 \pm 6.5$ & $3.05 \pm 0.38$ \\
400 & $383.1 \pm 12.3$ & $2.58 \pm 0.15$ \\
\hline
\end{tabular}




\subsection{Statistical analysis}

Results are presented as mean \pm SEM for each treatment. Statistical analysis used ANOVA followed by Dunnett's multiple-comparison tests (SPSS Software, version 10.0). The significance level was fixed at $\alpha<0.05$ throughout the study.

\section{Results}

\subsection{Tissue Cd accumulation}

Chronic exposure of tambaqui to dietary Cd resulted in a very high accumulation of the metal in tissues in the following order: kidney $>$ liver $>$ gills $>$ muscle

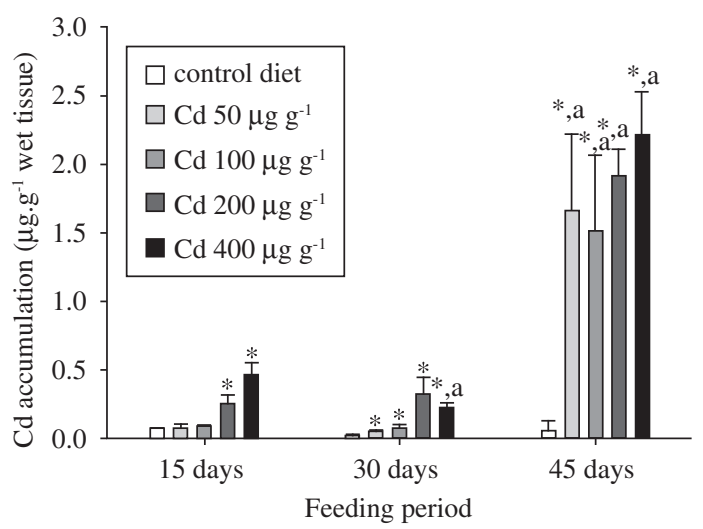

Figure 1. Muscle Cd concentrations (mean $\pm \mathrm{SEM}, \mathrm{N}=10$ ) in tambaqui chronically fed Cd-enriched diets. Asterisk (*) indicates significant difference relative to muscle samples from fish fed control diet ( $0 \mu \mathrm{g} . \mathrm{g}^{-1}$ dry food) at each sampling day, whereas (a) indicates significant differences in $\mathrm{Cd}$ concentrations over the feeding period, relative to the initial $15 \mathrm{~d}(\alpha<0.05)$.

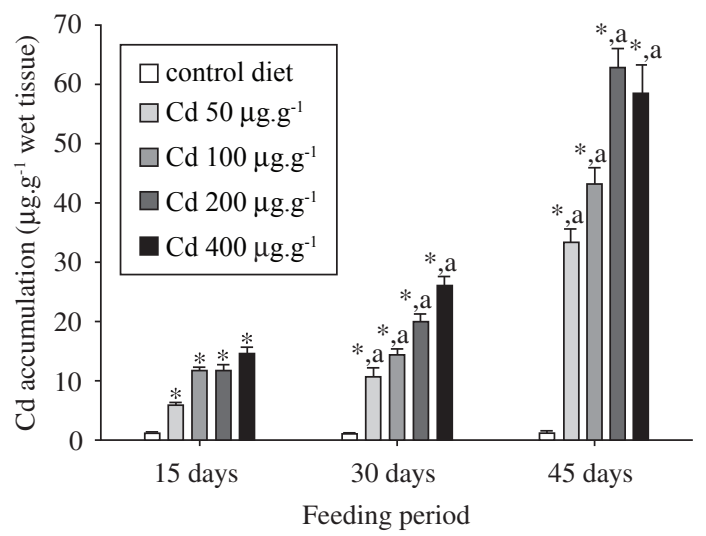

Figure 2. Gill Cd concentrations (mean \pm SEM, $N=10$ ) in tambaqui chronically fed Cd-enriched diets. Asterisk (*) indicates significant difference relative to gill samples from fish fed control diet ( $0 \mu \mathrm{g} \cdot \mathrm{g}^{-1}$ dry food $)$ at each sampling day, whereas (a) indicates significant differences in $\mathrm{Cd}$ concentrations over the feeding period, relative to the initial $15 \mathrm{~d}$ $(\alpha<0.05)$.
(Figures 1-4). Cd accumulation in sampled tissues generally increased over exposure time, and relative to the concentration of the metal in the diet. Tambaqui muscle tissue, used frequently as a protein source by the local population of the Amazon, had maximum Cd concentrations of up to $3.0 \mu \mathrm{g} . \mathrm{g}^{-1}$ wet tissue during the $45 \mathrm{~d}$ feeding trial (Figure 1). Detoxification sites, particularly liver and kidney, had maximum Cd concentration levels of approximately 140 and $500 \mu \mathrm{g}^{-g^{-1}}$ wet tissue (Figures 3-4).

\subsection{Specific growth rate}

Despite the high accumulation of $\mathrm{Cd}$ found in sampled tissues, no mortality occurred during the feeding period. There was also no apparent impairment in growth

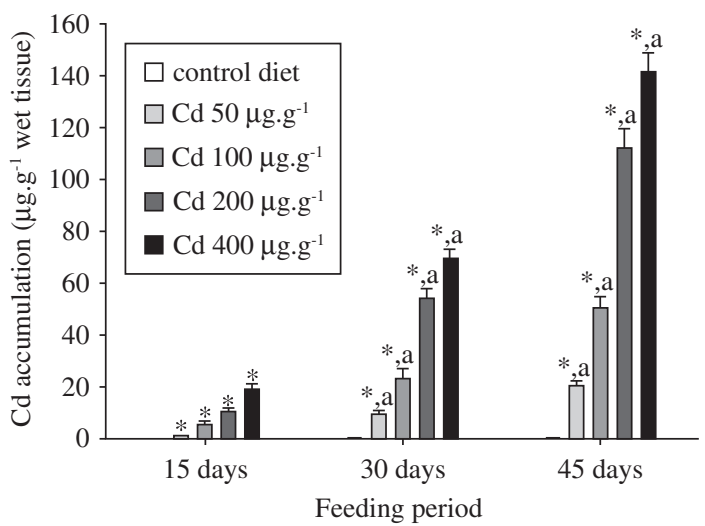

Figure 3. Liver Cd concentrations (mean $\pm \mathrm{SEM}, \mathrm{N}=10$ ) in tambaqui chronically fed Cd-enriched diets. Asterisk (*) indicates significant difference relative to liver samples from fish fed control diet ( $0 \mu \mathrm{g} \cdot \mathrm{g}^{-1}$ dry food $)$ at each sampling day, whereas (a) indicates significant differences in $\mathrm{Cd}$ concentrations over the feeding period, relative to the initial $15 \mathrm{~d}$ $(\alpha<0.05)$.

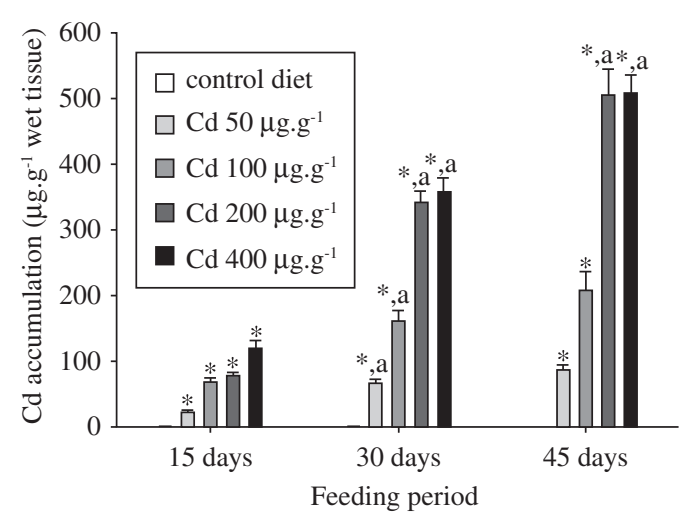

Figure 4. Kidney Cd concentrations (mean \pm SEM, $N=10$ ) in tambaqui chronically fed Cd-enriched diets. Asterisk (*) indicates significant difference relative to kidney samples from fish fed control diet ( $0 \mu \mathrm{g} \cdot \mathrm{g}^{-1}$ dry food) at each sampling day, whereas (a) indicates significant differences in $\mathrm{Cd}$ concentrations over the feeding period, relative to the initial $15 \mathrm{~d}(\alpha<0.05)$. 
during exposure to Cd-contaminated diets. Specific growth rate (SGR, \%/day) in tambaqui fed on different diets did not differ significantly among treatments (Table 1).

\section{Discussion}

Tambaqui is highly susceptible to waterborne $\mathrm{Cd}$ toxicity, as indicated by the persistent inhibition of $\mathrm{Ca}^{2+}$ uptake following acute exposure to the metal (Matsuo et al., 2005). Fish chronically fed Cd-enriched diets, however, did not show obvious signs of toxicity or growth impairment (Table 1), even though $\mathrm{Cd}$ accumulation in vital tissues (kidney, liver, gills) was high (Figures 2-4). Specific growth rates (SGR) were similar among treatments, as has been reported in rainbow trout (Oncorhynchus mykiss) fed diets containing Cd (Szebedinszky et al., 2001; Baldisserotto et al. 2005). The increased tolerance to dietary $\mathrm{Cd}$ toxicity in fish appears to involve increased induction of various cytosolic proteins with Cd-binding potential, the best known of these being the metallotioneins (MT) (e.g., Dang et al., 2001).

Chronic dietary $\mathrm{Cd}$ exposure in tambaqui resulted in accumulation of $\mathrm{Cd}$ in the kidney $>$ liver $>$ gills $>$ muscle (Figures 1-4), which agrees with the pattern of accumulation reported for rainbow trout (Szebedinszky et al., 2001). Quantitative differences relative to published studies, however, were remarkable: Cd accumulation in tissues of tambaqui through the dietary route was extremely high compared to values reported for rainbow trout (Szebedinszky et al., 2001; Baldisserotto et al., 2005). For example, kidney Cd accumulation in tambaqui had levels of up to $356 \mu \mathrm{g}$. $\mathrm{g}^{-1}$ wet tissue when fed a Cd-enriched diet of $400 \mu \mathrm{g} \cdot \mathrm{g}^{-1}$ dry food for $30 \mathrm{~d}$ (Figure 1), whereas in rainbow trout, kidney $\mathrm{Cd}$ accumulation was only $11 \mu \mathrm{g} \cdot \mathrm{g}^{-1}$ wet tissue in fish fed diets up to $1,500 \mu \mathrm{g} . \mathrm{g}^{-1}$ dry food for $36 \mathrm{~d}$ (Szebedinszky et al., 2001).

Interspecific differences in $\mathrm{Cd}$ tissue burden suggest that $\mathrm{Cd}$ accumulation from the diet may occur at much higher rates in tambaqui relative to rainbow trout. Apparently, a great portion of $\mathrm{Cd}$ ingested by rainbow trout is eliminated through the feces. Szebedinszky et al. (2001) documented very high Cd concentrations in feces $\left(\leq 244 \mu \mathrm{g} \cdot \mathrm{g}^{-1}\right)$ collected from the posterior rectum of rainbow trout fed diets containing Cd from 15 to $1,500 \mu \mathrm{g} . \mathrm{g}^{-1}$ dry food. Assuming that no significant absorption of $\mathrm{Cd}$ occurs from this intestinal segment on, we may also infer that a large portion of $\mathrm{Cd}$ fed to rainbow trout is eliminated through the feces. Similar results were found in tilapia (Oreochromis niloticus) fed diets containing $\mathrm{Cd}$ from 5 to $100 \mu \mathrm{g} \cdot \mathrm{g}^{-1}$ dry food, in which $\mathrm{Cd}$ content in feces were $\leq 279 \mu \mathrm{g} \cdot \mathrm{g}^{-1}$ (Nogami et al., 2000).

Although high concentrations of $\mathrm{Ca}^{2+}$ in either the water or the diet clearly have ameliorative effects on waterborne Cd toxicity in fish (e.g., Hollis et al., 2000; Zohouri et al., 2001; Baldisserotto et al., 2005), it is unclear whether the low water $\mathrm{Ca}^{2+}$ concentration in the holding tanks $\left(\sim 10 \mu\right.$ mol. $\left.\mathrm{L}^{-1}\right)$ contributed to amplify the dietary $\mathrm{Cd}$ accumulation in tambaqui. The sensitivity of tambaqui to waterborne $\mathrm{Cd}$ has been reported in a previous study (Matsuo et al., 2005), and the effect of soft water on dietary $\mathrm{Cd}$ accumulation still needs further investigation.

Cd concentrations in tambaqui muscle samples during our feeding trials were much lower (Figure 1) relative to other sampled tissues (Figures 2-4). The economical importance of tambaqui as a protein source among the population living in the Amazon should be emphasized in the context of metal bioaccumulation and transfer to consumers through the food chain.

We conclude that the tambaqui tolerate extended exposure to very high concentrations of dietary $\mathrm{Cd}$, and they accumulate remarkably high levels of the metal in their tissues, particularly in the kidney and liver. Despite the high tissue $\mathrm{Cd}$ burden, the species does not show reduced survival or impaired growth, at least during the $45 \mathrm{~d}$ feeding period we tested.

Acknowledgments - This work was supported by research grants from the Conselho Nacional de Desenvolvimento Científico e Tecnológico (CNPq) and Fundação de Amparo a Pesquisa do Estado do Amazonas (FAPEAM). We thank E.C. Chagas (Embrapa, Manaus, Amazonas) for the donation of experimental animals, all the colleagues that helped in tissue sampling, and C.A. Marantz for reviewing this manuscript.

\section{References}

BALDISSEROTTO, B., CHOWDHURY, MJ. and WOOD, CM., 2005. Effects of dietary calcium and cadmium on cadmium accumulation, calcium and cadmium uptake from the water, and their interactions in juvenile rainbow trout. Aquat. Toxicol. vol. 72, nos. 1/2, p. 99-117.

BERNTSSEN, MHG., WAAGBO, R., TOFTEN, H. and LUNDEBYE, AK., 2003. Effects of dietary cadmium on calcium homeostasis, Ca mobilization and bone deformities in Atlantic salmon (Salmo salar L.) parr. Aquac. Nutrit. vol. 9, no. 3 , p. $175-183$.

DANG, ZC., BERNTSSEN, MHG., LUNDEBYE, AK., FLIK, G., BONGA, SEW. and LOCK, RAC., 2001. Metallothionein and cortisol receptor expression in gills of Atlantic salmon, Salmo salar, exposed to dietary cadmium. Aquat. Toxicol. vol. 53, no. 2, p. 91-101.

FURCH, K., 1984. Water chemistry of the Amazon Basin: The distribution of chemical elements among freshwaters. In SIOLI, H. (ed.), The Amazon, Limnology and Landscape Ecology of a Mighty Tropical River and its Basin. Dr. W. Junk Publishers, Dordrecht, p. 167-199.

HOLLIS, L., MCGEER, JC., MCDONALD, DG. and WOOD, CM., 2000. Protective effects of calcium against chronic waterborne cadmium exposure to juvenile rainbow trout. Environ. Toxicol. Chem. vol. 19, no. 11, p. 2725-2734.

MATSUO, AYO., VAL, AL. and WOOD, CM., 2005. Effects of copper and cadmium on ion transport and gill metal binding in the Amazonian teleost tambaqui (Colossoma macropomum) in extremely soft water. Aquat. Toxicol. vol. 74, no. 4, p. 351-364.

NOGAMI, EM., KIMURA, CCM., RODRIGUES, C., MALAGUTTI, AR., LENZI, E. and NOZAKI, J., 2000. 
Effects of dietary cadmium and its bioconcentration in tilapia Orecohromis niloticus. Ecotoxicol. Environ. Saf. vol. 45, no. 3, p. 291-295.

OLIVEIRA, CPF., 2003. Efeito do cobre e chumbo, metais pesados presentes na água de formação derivada da extração do petróleo da província petroleira do Urucu - AM, sobre o tambaqui, Colossoma macropomum (Cuvier, 1818). Unpublished M.Sc. Thesis, INPA/UFAM (Instituto Nacional de Pesquisas da Amazônia/Universidade Federal do Amazonas), Manaus, Amazonas, 70p.

PLAYLE, RC., DIXON, D. and BURNISON, K., 1993. Copper and cadmium binding to fish gills: estimates of metal-gill stability constants and modeling of metal accumulation. Can. J. Fish. Aquat. Sci. vol. 50, no. 12, no. 3, p. $2678-2687$.
SZEBEDINSZKY, C., MCGEER, JC., MCDONALD, DG. and WOOD, CM., 2001. Effects of chronic Cd exposure via the diet or water on internal organ-specific distribution and subsequent gill $\mathrm{Cd}$ uptake kinetics in juvenile rainbow trout (Oncorhynchus mykiss). Environ. Toxicol. Chem., September, vol. 20, p. 597-607.

VERBOST, PM., VAN ROOIJ, J., FLIK, G., LOCK, RAC. and WENDELAAR BONGA, SE., 1989. The movement of cadmium through freshwater trout branchial epithelium and its interference with calcium transport. J. Exp. Biol. vol. 145, p. 185-197.

ZOHOURI, MA., PYLE, GG. and WOOD, CM., 2001. Dietary $\mathrm{Ca}$ inhibits waterborne $\mathrm{Cd}$ uptake in Cd-exposed rainbow trout, Oncorhynchus mykiss. Comp. Biochem. Physiol. vol. 130c, no. 2/3, p. 347-356. 